\title{
Introduction
}

\section{to the 1969 Edition}

The five Central American nations claim a mutual economic and social history resulting from a shared geopolitical destiny. Few historical investigations exist that examine the economic and social formation of Central America, and even fewer that furnish a perspective respectful of local differences. This book represents an attempt, without distorting regional conditions and disregarding local agents, to achieve a global perspective of the forces that favored and impeded development. This work, therefore, examines the social development of Central America.

Some analytical schemes and structural observations are employed to explain development. For this reason, and for the limitations discovered in the bibliographical sources and documents, the work has a provisional objective that underlines the preliminary character of the hypothesis and proposed explanations. At the very least, the results are susceptible to total or partial modification in the future.

One crucial question in this study considers the formation of the nation-state, that is, the possibility of a greater or lesser degree of autonomy achieved by Central American society as a whole and as a national expression of the domestic and foreign forces present in its formation. Economic factors by themselves do not clarify the bonds of dependence and interdependence or the forms of modernization if not compared simultaneously with the activity of social groups and classes, their relations, commitments, and conflicts.

The effective linking of the Central American economy to the world market constitutes our point of departure. This linking, actualized through an export agricultural product, implied the participation of local producers and the consequent restructuring of domestic institutions. The stage prior to this strategic moment constituted only frustrated efforts at establishing a central power in response to the political rupture with Spain. The civil war that led to the dissolution of the federal covenant demonstrated the failure to produce a viable economic and political alternative. Instead, a vigorous colonial and economic inherit- 
ance prevailed for years following 1821 . With the exception of Honduras, Central America began to mold itself as an agro-export society through the emergence of coffee. In Honduras, first mining and then bananas constituted the principal economic activity.

The bonds of dependency to the world market acquired a new dimension with the formation of the banana enclave, the first appearance of North American capital in Central America. Although the enclave functioned only in Guatemala, Honduras, and Costa Rica, it affected the entire region's political and social life, markedly so in Honduras. The export economy expedited liberal "reformism" in Central America during the last decades of the nineteenth century and thus laid the foundation of the present five Central American republics. The banana enclave transcended itself and established ties with society through monopolisitic control of communication and transportation facilities (railroad, ports, and navigation). Beginning with these events, the commitment between foreign interests and the coffee oligarchy became essential for comprehending the limits and peculiarities of Central American development. From this perspective, agro-export activity exhibited its insurmountable contradictions and limitations and eclipsed any possibility of self-sustaining growth. By the 1930s, the Central American republics were agrarian appendices of the central economies. The leading groups, furthermore, neither had nor could have had any interest in overcoming the constituted order built on two focal points: a social structure established on an economic unity, the hacienda, and its patrimonial relationship with campesino peonage; and a political order, authoritarian and exclusive, fashioned through foreign sources of power, the supportive banana enclave interests, and its North American capital.

The world crisis of the 1930s marked the beginning of the crisis of the liberal republic and the structures tied to coffee. The power of persistent historical norms was exposed. These norms, by their magnitude and duration, demonstrated the weakness of the agro-export economy. Toward the end of the second postwar period, this economic system and its dictatorships stagnated. The limited democratic possibilities offered by the oligarchy diminished under historical pressure. At this point, as at others, Costa Rica was an exception to such generalization.

Two decades elapsed between 1944 and the slow consolidation of economic integration. The breach between the interests of the landholding oligarchy and those of the people who supported economic diversification stimulated a relative opening of the political system. On the one hand, portions of the urban middle class manipulated popular discontent; on the other, various vested interests pushed for industrialization. 
A new push toward development expanded the functions of the state. Under the state's direction, agro-export interests ceased to hold sway. With the exception of Guatemala, popular movements, which shook Central America in the first years of the postwar period, introduced only slight modifications into the political system and within the mobilization created by industrialization. The common market emerged as the only alternative, almost as an obligatory step toward constructing an economic and institutional framework within which the whole society would be energized. The most significant economic events of this period were the emergence of cotton and, to a lesser extent, sugar and beef, which contributed to the diversification of foreign trade; accelerated capitalization in the countryside; the camouflage or decline of the fruit enclave, especially in Guatemala and Costa Rica; the appearance of North American capital in local industry, associating itself with or displacing national producers; and a vigorous, but artificial, momentum in Central American domestic commercial activity. With the meaningful "deviation" of Costa Rica (more in form than in content and direction), the landholding oligarchy, the industrialists, and the merchants attempted to resolve the causes of the political crises and the ambiguities and limitations of the process of change by means of authoritarian governments. These combined forces outlawed social struggles, excluded other sectors from the political arena, and fomented industrialization by sacrificing autonomy to the process of development. 
THIS PAGE INTENTIONALLY LEFT BLANK 
History and Society in Central America 
THIS PAGE INTENTIONALLY LEFT BLANK 